\title{
RANCARE RATIONING - MISSED NURSING CARE: AN INTERNATIONAL AND MULTIDIMENSIONAL PROBLEM- SPRAWOZDANIE Z PIERWSZEGO SZKOLENIA ANNUAL TRAINING SCHOOL - 2017 W TURKU (FINLANDIA)
}

\section{RANCARE RATIONING - MISSED NURSING CARE: AN INTERNATIONAL AND MULTIDIMENSIONAL PROBLEM - REPORT ON THE FIRST TRAINING AT ANNUAL TRAINING SCHOOL - 2017 IN TURKU (FINLAND)}

Jarosława Belowska1, Lucyna Iwanow ${ }^{1}$, Izabella Uchmanowicz² ${ }^{2}$ Joanna Gotlib ${ }^{1}$

\author{
${ }^{1}$ Zakład Dydaktyki i Efektów Kształcenia, Wydział Nauki o Zdrowiu \\ Warszawski Uniwersytet Medyczny \\ ${ }^{2}$ Katedra Pielęgniarstwa Klinicznego, Zakład Pielęgniarstwa Internistycznego \\ Uniwersytet Medyczny im. Piastów Śląskich we Wrocławiu
}

DOI: https://doi.org/10.20883/pielpol.2018.28

W dniach 18-22 września 2017 roku w Turku w Finlandii odbyło się pierwsze z serii szkolenie ANNUAL TRAINING SCHOOL - 2017, organizowane w ramach projektu badawczego RANCARE Rationing - Missed Nursing Care: an International and Multidimensional Problem współfinansowanego przez Unię Europejską i realizowanego w ramach Europejskiego Programu Współpracy w dziedzinie badań naukowo-technicznych-AkcjaCOST CA15208 - Cooperation in Science and Technology w Programie Ramowym Horyzont 2020. W pilotażowym szkoleniu w Turku brały udział doktorantki mgr Jarosława Belowska i mgr Lucyna Iwanow, reprezentantki Zakładu Dydaktyki i Efektów Kształcenia Wydziału Nauki o Zdrowiu Warszawskiego Uniwersytetu Medycznego, oraz dr Beata Jankowska-Polańska, dr Anna Chudiak, dr Anna Rozensztrauch, mgr Katarzyna Lomper, mgr Magdalena Lisiak oraz mgr Marta Wleklik z Uniwersytetu Medycznego im. Piastów Śląskich we Wrocławiu.

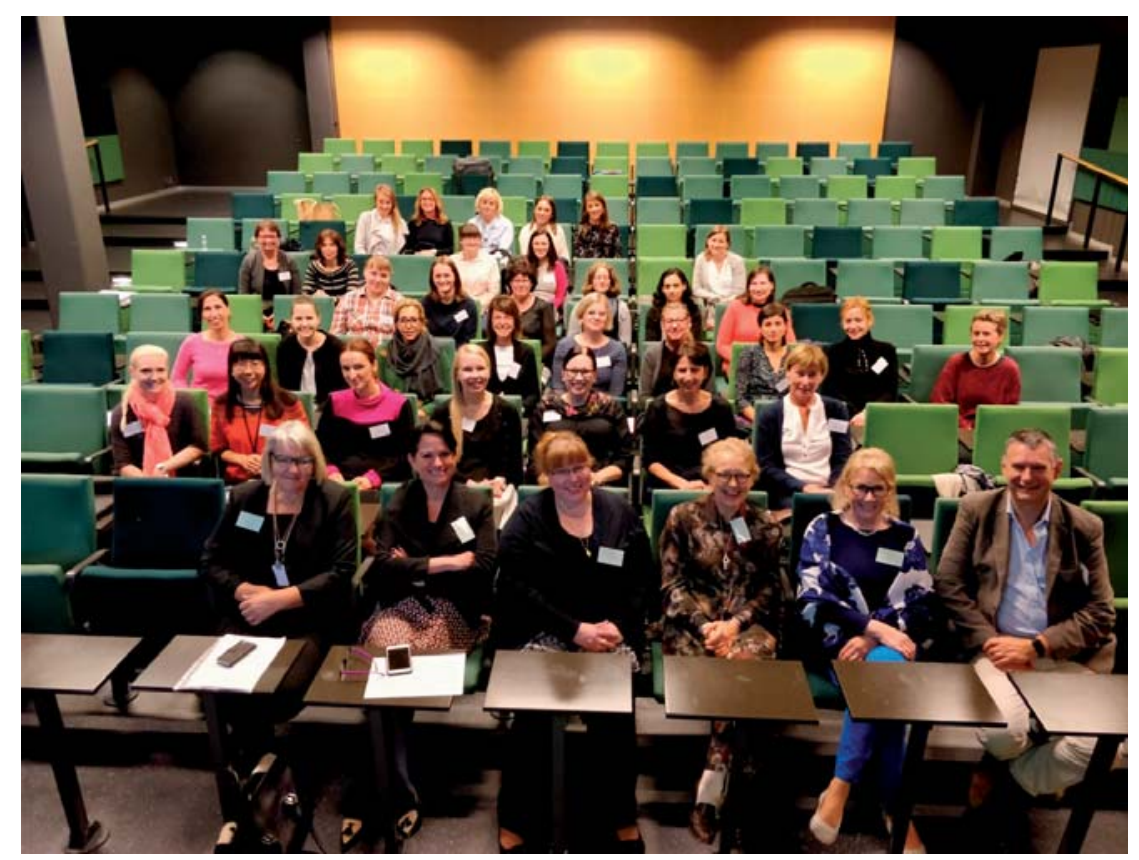

Rycina 1. Uczestnicy szkolenia RANCARE Rationing - Missed Nursing Care wraz z nauczycielami Źródło: fotografia autorstwa jednej z uczestniczek szkolenia 


\section{RANCARE Rationing - Missed Nursing Care}

Pojęcie utraty opieki pielęgniarskiej (ang. missed nursing care) zostało po raz pierwszy zastosowane w 2006 roku przez amerykańską pielęgniarkę Beatrice J. Kalisch [1]. Missed nursing care jest błędem pominięcia i odnosi się do każdego aspektu wymaganej opieki nad pacjentem, która została pominięta, w części lub w całości. Oznacza to, że niektóre elementy opieki pielęgniarskiej są wykonywane z opóźnieniem, a tylko część udaje się sukcesywnie zakończyć [2]. Uważa się, że problem ten występuje na całym świecie i bezpośrednio zagraża bezpieczeństwu pacjenta we wszystkich krajach i kulturach [1, 2]. Ponadto Kalisch i wsp. opracowali koncepcyjny model zaniedbanej opieki pielęgniarskiej. Zgodnie z jego założeniami czynniki strukturalne przyczyniające się do opuszczenia opieki obejmują: zasoby pracy, zasoby materialne oraz pracę zespołową i komunikację. Jeśli brakuje któregokolwiek z tych zasobów, pielęgniarki są zobowiązane do priorytetowego traktowania swoich zadań i obowiązków, a w danej chwili opieka pielęgniarska może zostać opóźniona lub pominięta. Obecnie najważniejszymi czynnikami predykcyjnymi utraty opieki pielęgniarskiej są poziom zatrudnienia i praca zespołowa [1]. Mając na uwadze zmagania systemu ochrony zdrowia z globalnym brakiem pielęgniarek, brak opieki lub jej pominięcie jest powszechnym zagrożeniem, mogącym prowadzić do niebezpiecznych błędów medycznych [1].

W 3-letnim projekcie RANCARE (planowana data zakończenia: wrzesień 2019 roku) udział bierze 84 przedstawicieli z 27 krajów [3]. Przedstawicielami Polski w projekcie RANCARE są dr hab. n. o zdr. Joanna Gotlib reprezentująca Zakład Dydaktyki i Efektów Kształcenia Wydziału Nauki o Zdrowiu Warszawskiego Uniwersytetu Medycznego oraz dr hab. n. o zdr. Izabella Uchmanowicz z Zakładu Pielęgniarstwa Internistycznego Katedry Pielęgniarstwa Klinicznego Wydziału Nauki o Zdrowiu Uniwersytetu Medycznego we Wrocławiu. Głównym celem projektu jest podjęcie dyskusji na temat wpływu niewystarczającej, w większości krajów świata, obsady pielęgniarskiej na praktykę pielęgniarską: jakość opieki i bezpieczeństwo pacjenta, jak również konsekwencji braku wystarczającej opieki pielęgniarskiej dla rozwoju zawodowego pielęgniarek. Poprawa obecnej sytuacji ma zostać osiągnięta poprzez pogłębianie współpracy pomiędzy pochodzącymi z różnych krajów przedstawicielami reprezentującymi różne dziedziny wiedzy: pielęgniarkami, lekarzami, specjalistami zdrowia publicznego, ale również etykami oraz specjalistami w obszarze badań naukowych w naukach o zdrowiu [3].
W projekcie RANCARE Rationing - Missed Nursing Care ujęto osiem obszarów, w których prowadzone będą badania i analizy:

1) wypracowanie wspólnej definicji pojęcia racjonowania opieki pielęgniarskiej;

2) wskazanie najważniejszych czynników związanych z systemem racjonowania opieki pielęgniarskiej oraz wskazanie nowych kierunków badań w tym obszarze;

3) wskazanie obszarów do dyskusji na temat bezpieczeństwa pacjentów oraz jego miejsca w programach kształcenia na kierunku: pielęgniarstwo;

4) wskazanie obszarów do dyskusji na temat etycznego wymiaru racjonowania opieki pielęgniarskiej;

5) analiza i wskazanie najważniejszych kompetencji wymaganych do kształcenia w zakresie podejmowania decyzji i ustalania priorytetów w opiece pielęgniarskiej;

6) analiza i wskazanie metod oceny i sposobów badania racjonowanej opieki pielęgniarskiej;

7) wskazanie interwencji pielęgniarskich opartych na dowodach naukowych;

8) rozpowszechnienie wyników badań w grupie interesariuszy zewnętrznych reprezentujących różne kraje: pielęgniarskich organizacji zawodowych i naukowych, stowarzyszeń pacjentów, kadry zarządzającej szpitalami i innymi placówkami ochrony zdrowia [3].

\section{Missed Nursing Care - ANNUAL TRAINING SCHOOL 2017}

Celem pierwszego szkolenia z projektu RANCARE było wzmocnienie wspólnej świadomości w zakresie pojęcia utraty opieki pielęgniarskiej oraz zapoczątkowanie tworzenia sieci kontaktów wspierających wymianę wiedzy oraz rozpowszechniania dobrych praktyk pielęgniarskich na szczeblu zarówno europejskim, jak i światowym.

Uczestnikami projektu były pielęgniarki i specjaliści nauk pokrewnych, posiadający stopień naukowy doktora bądź będący na studiach doktoranckich, reprezentujący trzynaście państw (Bośnię i Hercegowinę, Cypr, Czechy, Finlandię, Grecję, Irlandię, Litwę, Niemcy, Norwegię, Polskę, Szwajcarię, Wielką Brytanię oraz Włochy). Uczestnicy podzieleni zostali na dwie grupy. Grupa pierwsza zajmowała się aspektem etycznym racjonowania opieki pielęgniarskiej, natomiast grupa druga - aspektem teoretycznym tego zagadnienia. Opiekunami grupy etycznej byli prof. Helena Leino-Kilpi oraz prof. Riitta Suhonen z Uniwersytetu w Turku (Finlandia), a także prof. Anne Scott z Uniwersytetu 
w Galway (Irlandia). Grupę teoretyczną prowadzili dr Anat Drach-Zahawy, psycholog z Uniwersytetu w Hajfie (Izrael), prof. Terry L. Jones, pielęgniarka z Uniwersytetu w Virginii (USA), oraz prof. Walter Sermeus z Uniwersytetu w Leuven (Belgia).

Każdy dzień szkolenia podzielony był na cztery bloki zajęciowe, naprzemiennie dwa wykłady dla wszystkich uczestników projektu oraz dwa seminaria do pracy w grupach.

Na wykładach poruszano zagadnienia teoretyczne, które wprowadzały do pojęć, wokół których oscylował cały kurs i pozwalały je dokładniej zrozumieć. Zajęcia seminaryjne z kolei były rozwinięciem zagadnień poruszanych na wykładach. Dodatkowo omawiano tematykę związaną z prowadzeniem projektów badawczych. Podczas tych zajęć każdy uczestnik grupy teoretycznej mógł opowiedzieć o swoim projekcie naukowym oraz zastanowić się, jak wpisuje się on w cele RANCARE.

Poza zajęciami merytorycznymi organizatorzy przewidzieli też część integracyjną. Pierwszego dnia, po zajęciach, odbyło się spotkanie zapoznawcze uczestników wraz z organizatorami i liderami szkolenia. Następnego dnia przewidziano spacer i zwiedzanie miasta
Turku. Najciekawszą atrakcją okazało się jednak zwiedzanie szpitala uniwersyteckiego w Turku. Po szpitalu oprowadzał pracownik działu logistycznego, a na poszczególnych oddziałach rolę przewodnika przejmował personel pielęgniarski. Przedostatniego dnia szkolenia odbyła się uroczysta kolacja w muzeum w Turku Aboa Vetus. Spotkanie rozpoczęło się zwiedzaniem pozostałości po średniowiecznym mieście i oficjalnym toastem lokalnych władz rządzących.

Szkolenie zorganizowane w ramach projektu RANCARE dało możliwość wymiany doświadczeń na polu międzynarodowym. Uczestnicy projektu chętnie omawiali rozwiązania, jakie zostały zastosowane w ich państwach, ale też mówili o problemach i dylematach, jakie stoją przez pielęgniarkami na całym świecie w związku z globalną niedokończoną opieką pielęgniarską.

\section{Piśmiennictwo}

1. Uchmanowicz I. Missed nursing care - what went wrong? Centr Eur J Nurs Midwifery. 2017; 8 (2): 609.

2. Kalisch BJ, Landstrom GL, Hinshaw AS. Missed nursing care: a concept analysis. J Adv Nurs 65 (7): 1509-1517.

3. (Dostępne w Internecie:) https://www.rancare-action.eu/ 